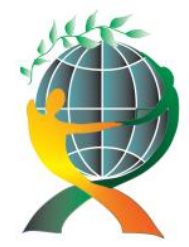

\author{
(online) $=$ ISSN $2285-3642$ \\ ISSN-L = $2285-3642$ \\ Journal of Economic Development, Environment and People \\ Volume 1, Issue 3, 2012 \\ URL: http://jedep.spiruharet.ro \\ e-mail: office jedep@spiruharet.ro
}

\title{
Economy Development: Benchlearning
}

\author{
Ph.D. Malobabic Vanja \\ PC Sports and business Center Vojvodina, SC Sajmiste-Sutjeska 2; \\ Hajduk Veljkova 11a,21000 Novi Sad,Serbia \\ vanja.malobabic@spens.rs,banezim@eunet.rs
}

\begin{abstract}
Benchlearning like new method integrates efficient methods and human development at a time when such integration is recognized as increasingly vital to organizational success. It:

-offers practical inspiration on improving quantitative goals

-company performance and competitiveness-by influencing the attitudes of people within the organization

-provides a new method combining the qualities of both the learning organization and knowledge management

-shows how this concept can be applied using case studies and illustrations and the result of pilot project

-describes practical perspectives and tools on management and learning theory.

This work will be invaluable to senior and middle managers, consultants and practitioners and MBA students, as well all those working within organizations that are keen to improve and develop their performance.

The aim is to produce a business strategy which will make organizations work more efficiently.

Different aspects of 'the economics of learning' have been the main content research.

This work answers the question 'how do you know that your operation is efficient?'Benchlearning show that it is possible to move on from pure comparison to benefit from the knowledge and experience of others and create a real learning organization. Examples from a range of organizations including Ericsson show how to monitor efficiency, provide inspiration for a development drive, and illustrate how to influence people's experience, in combination with the principles of organizational learning.

Benchlearning principles can be applied to almost any group or company to promote a win-win-win situation: employees' performance improves as they learn to develop, customers gain more value and choice, and owners benefit from a more competitive organization.
\end{abstract}

Keywords: development, benchlearning, consultants

\section{JEL Codes: F63, D 83}




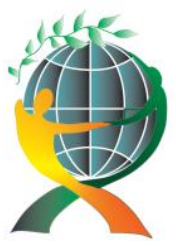

\author{
(online) $=$ ISSN $2285-3642$ \\ ISSN-L = $2285-3642$ \\ Journal of Economic Development, Environment and People \\ Volume 1, Issue 3, 2012 \\ URL: http://jedep.spiruharet.ro \\ e-mail: office jedep@spiruharet.ro
}

\title{
1. Introduction
}

The fundamentals of learning and how benchlearning fits into the context:

- understanding: benchlearning leads to it

- competence of economic value: what benchlearning aims at

- tacit knowledge: benchlearning is a concept for transferring not only calibrated key indicators and pre-codified data but also tacit knowledge, which is harder to access

- transformations between tacit and codified knowledge: benchlearning creates a learning environment in which both 'sender' and 'receiver' are forced to make their insights explicit and create the interactions that accelerate achievement of awareness

- models and diagrams: benchlearning leads to understanding of other people's models; this can prompt revision of ideas about the logic of one's own business

- objectivisation: benchlearning accelerates this process

- models: benchlearning offers a method that enables us to reappraise faulty or obsolete models and 'update' our perception of reality

- group-based learning: benchlearning provides opportunities for throwing light on the business from several angels and reinforces cohesion in the group

- absorptive capacity: the group's analysis of the problem and its choice of good example lay a firm foundation for absorptive capacity

- complexity: benchlearning furnishes the vaulter whith a pole without whose help he could never attain the necessary height

- faster processes: benchlearning accelerates learning

- strategy: benchlearning trains strategic thinking ability in those levels of the company where it is most needed

- social competence: benchlearning develops social competence, both through interaction with the good example and within the group itself.

What requirements should modern corporate education satisfy? I shall now formulate some of the requirements that can reasonably be expected of a modern method for corporate development and learning, and discuss how benchlearning relates to requirements and how it fits in with existing theories of occupational learning. 


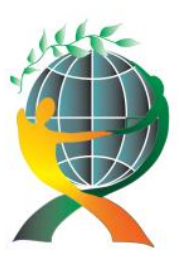

\author{
(online) $=$ ISSN $2285-3642$ \\ ISSN-L = $2285-3642$ \\ Journal of Economic Development, Environment and People \\ Volume 1, Issue 3, 2012 \\ URL: http://jedep.spiruharet.ro \\ e-mail: office jedep@spiruharet.ro
}

\title{
2. Integration of Learning and Eficiency
}

We have called benchlearning a concept for corporate development and knowledge formation. By doing so we want to make the point that any concept for occupational or corporate learning must have efficiency as its aim and must be in line with the overall aims of the company or organisation. We further maintain that development of the company that is to be sustainable in the long term must be based on knowledge formation. The problem with many approaches is that they fail to combine these aspects. In the field of business administration, as we mentioned in the introduction to this work, the realisation that knowledge formation and learning are crucial to corporate development is relatively recent. In addition, business administration approaches to learning have often operated on a highly aggregated and thus abstract level. Theorists have often viewed organisations as the learning subjects and have thus been unable to convincingly link their ideas to the finding of educational science or cognitive psychology. And those who specialise in developing ideas about learning have seldom come from disciplines or backgrounds that require concepts like efficiency and competitiveness to be incorporated into empirical or theoretical work.

Any attempt to devise an approach to learning without integrating it with a company's demand for efficiency, however well-meaning, is doomed to failure. We are thus faced with a need to integrate efficiency with learning, as well as to integrate the individual's need to develop with the company's overall aims.

Benchlearning offers a way to integrate these factors. There are, as we mentioned earlier, other methods that try to place learning in a perspective of efficiency, but they are far too few and exist at present only as theories. By developing the benchlearning concept we also want to stimulate discussion and development of other ideas which seek to achieve integration of learning and efficiency.

\section{Faster Learning}

A modern development concept must be capable of accelerating learning and handling a growing degree of complexity.

That requirement could be formulated as a number of sub-requirements:

- to furnish the company/group with a tool enabling it to use prior knowledge as a lever for new knowledge formation

- to offer guidance and serve as a compass to indicate the direction in which new knowledge should be sought 


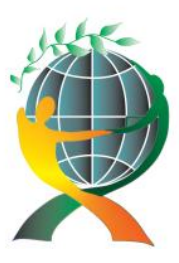

\author{
(online) $=$ ISSN $2285-3642$ \\ ISSN-L = $2285-3642$ \\ Journal of Economic Development, Environment and People \\ Volume 1, Issue 3, 2012 \\ URL: http://jedep.spiruharet.ro \\ e-mail: office jedep@spiruharet.ro
}

- to raise the company's aspirations to a high yet realistic level

- to promote better understanding of one's own business and its logic and context.

The concept is based on what is perhaps the most important kind of knowledge formation, the proposition that utilisation of prior knowledge is the starting point for producing new knowledge, finding solutions to new problems, developing a new product, and so on.

The instructive power of good examples likewise guides the search for knowledge in a given direction. The desire to use the best practice in a given field as a source of inspiration and point of comparison not only provides input for the effective transfer of knowledge but is also a method that influences the level of aspiration: 'If they can do it, why can't we?' The fact that the source of inspiration to which one turns has actually run an operation that works in both theory and practice naturally enhances the value of the information obtained from that source.

Application of the instructive power of good examples has the further advantage that those who are seeking to improve their efficiency have absorptive capacity in the area of knowledge to be transferred. They have experience, they have worked on the same problems themselves, and they know is needed to make further progress. Here, too, the concept agrees with research in the field.

The principle of 'seeing ourselves in others' can also be applied to corporate development and knowledge formation.

To return to modern theories of education and cognitive psychology, our contention is that benchlearning enables us to objectivise our own business. The existence of several objects provides input for gaining new perspectives on our own business. From that position we can formulate a number of hypotheses about our business, and then convert them into plans of action to improve our operations. The opportunity that benchlearning offers to objectivise our business this way and to establish a greater number of interactions between our own understanding and the world around us accelerates the learning process.

Benchlearning is thus strategy that aims at giving people a greater understanding of the relationships and logic that influence their daily work. Another important point here is that benchlearning also tries to identify the mental models which influence and perhaps even control the actions of our good examples. Without that, we risk trying to study behaviour in isolation while ignoring the reasons for such behaviour. By studying our examples 'mental models, on the other hand, we achieve understanding and with it the ability to use our benchlearning partners' experience creatively.

Benchlearning solves yet another problem which seems to be intimately associated with a turbulent economy - the lack of natural opportunities to reflect on and evaluate one's own business - when the focus is on quik and specific learning, or just-in-time learning. 


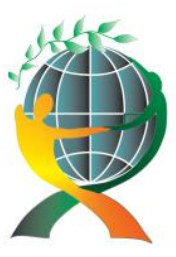

\author{
(online) $=$ ISSN $2285-3642$ \\ ISSN-L = $2285-3642$ \\ Journal of Economic Development, Environment and People \\ Volume 1, Issue 3, 2012 \\ URL: http://jedep.spiruharet.ro \\ e-mail: office jedep@spiruharet.ro
}

The opportunities that a benchlearning project provides for reflection may also explain the frequently observed phenomenon in benchmarking that it is easy to recruit those seen as good examples as partners in such projects. It is the opposite that is difficult - that is, getting less advanced companies to agree to such a project. One possible explanation for this is that the good company has attained its position because it has always focused its attention on the world around it and not on its own problems. The self-confidence inspired by the appreciation of one's peers also undoubtedly plays a part, as does the prestige of being held up as a good example. But on top of that, even the good example has a need to articulate and evaluate its experience, and have it illuminated by the questions put by potential partners, such as in a benchlearning project. Such a project requires them to formulate their experience for the benefit of external partners, and to do that the company must itself articulate, codify and evaluate its own experience. With the help of a consultant and partners, the good example can also acquire a deeper understanding of its own business.

\title{
4. Universal Participation
}

The turbulent economy makes new demands on knowledge formation among organisations and their employees. We have seen how the type of organisation based between departments and units has increasingly given way to the ad hoc kind of organisation where total responsibility for a project placed in the hands of a group. Information management is being decentralised, even as management has acquired better means of central control. In many cases this may be seen as a necessary condition for delegation of information management and decision-making responsibility to those people within the organisation who actually have to get the job done.

These changes have focused an unprecedented amount of attention on the individual employee and the smallest production unit. The supervisors and middle managers who previously made decisions about what to do, how to do it and when to do it have been largely eliminated. In a turbulent economy a company cannot afford the time it takes for a problem or decision to filter through the hierarchy and risk being delayed on the way. To avoid unnecessary delay, the problem, and decisions on how to deal with it, are now handled by those responsible for doing the actual work.

A further consequence of the turbulent economy is that the practice of setting up a strategic planning system at top management level is no longer used. If the future is difficult to predict, a long-term strategy is impossible to implement. A better option is to develop the company's adapatability and flexibility. But that does not remove the necessity for the various units of the company to formulate plans of action for their own operations. In one way or another, people are forced to make a series of decisions about a future which they cannot foresee. It is therefore important that the company's employees and working groups are trained in strategic thinking. Benchlearning provides opportunities for doing that. 


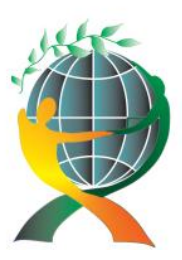

\author{
(online) $=$ ISSN $2285-3642$ \\ ISSN-L = $2285-3642$ \\ Journal of Economic Development, Environment and People \\ Volume 1, Issue 3, 2012 \\ URL: http://jedep.spiruharet.ro \\ e-mail: office jedep@spiruharet.ro
}

There are also other factors behind these developments. The increasing emphasis on quality means that the individual employee must be enabled to develop their own competence and to take responsibility for their own work. In addition, the presure for efficiency generated by increasing competition and demands for transparency means that ancillary costs such as production and quality control must be integrated with, not isolated from, the work process. This further stresses the relevance of the adage that 'no chain is stronger than its weakest link'.

But this also means that the process of development, including the strategic aspects that apply to the group or project, can be efficient only if everybody concerned participates in the effort. This probably also something which appeals to the members of the group and reinforces their sense of security and common purpose.

In the matter of comparisons with good examples, there is a further motive for placing responsibility for the development project in the team's own hands. A process of development based on comparison with an advanced example may create misgivings about its purpose. If it is 'proved' that somebody out there has solved this problem better than we have, that can be used in in-house discussion as a stick with which to beat the unit concerned, which will therefore do all it can to avoid getting involved in such processes. But if the group itself is in control of the project, that not only inspires confidence but also a knowledge-seeking attitude which guarantees that the company will have an absorptive capacity that can understand, evaluate and use the information which it acquires. It is very hard for those who are not in daily contact with an operation to judge from outside how the partner's experience can be evaluated and used by those who bear the operative responsibility in their own company.

Putting the group in charge of its own project is also important as an aid to learning. Learning means that the people involved acquire a better understanding of their work. An individual who has done that is more autonomous. It is thus important that an individual's influence over their job should match the new autonomy, and that the organisation should allow the individual and the group to experiment so as avoid placing needless obstacles in the way of learning by inhibiting opportunities for interaction between individuals, actions and results.

Benchlearning further encourages the development of an extroverted, inquisitive organisation. The realisation that there are always good examples to be found is incompatible with smugness and a selfglorifying style of management. To be capable of benefiting from externally generated knowledge, an organisation must instead cultivate a corporate culture that is analytical and open. Groups whose memebership is variegated in terms of experience, sex and ethnicity enjoy an advantage over homogeneous groups when it comes to taking the broad view and identifying interesting opportunities for development. 


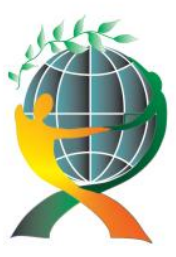

\author{
(online) $=$ ISSN $2285-3642$ \\ ISSN-L = $2285-3642$ \\ Journal of Economic Development, Environment and People \\ Volume 1, Issue 3, 2012 \\ URL: http://jedep.spiruharet.ro \\ e-mail: office jedep@spiruharet.ro
}

Even if it is the group that owns a benchlearning project, that does not make the role of the corporate management any less important. Managers, for the most part, set the rules within the company and set their stamp on corporate culture. The individual, for the sake of their own development and involvement, needs to be given new varied assgnments to tackle. Managers' attitudes to regular job-swapping and job rotation are very important in this respect. Does the company offer attractive career opportunities? Does it offer tangible rewards to those try to learn new skills and improve themselves? Does it encourage collaboration or internal competition? Does it organise regular apparaisal interviews individual employees and, if so, how are they followed up? Are there opportunities for refresher training for employees who want to update their knowledge and thereby enhance the comany's ability to learn and use new technology and methods? Those are just some of the questions that managers should consider if they want to encourage the personal development of their employees.

\title{
5. Benchlearning - A Synthetic, Integrating Approach
}

In the current discussion of corporate development and knowledge formation, it is popular to trumpet highly simplified, one-dimensional messages. Many concepts are touted as the new and only road to salvation. There is of course a risk that bench-learning may be regarded as just another these fads. But because benchlearning uses knowledge that already exists, we maintain that benchlearning is a synthetic, integrating approach which - like all other concepts - has important elements in common with other theories.

Equally evident are mutual give-and-take and co-existence with a number of other theories, both those that we have mentioned here and others. They include benchmarking, balanced scorecard, continual improvement, knowledge management, action research, democratic dialogue, lessons learned, peer groups and network theories of a more general nature. Which theory or technique a company should use depends on many factors, primarily the type of problem it is trying to solve. If it wants to enable employees at their computer screens to click their way to useful hints, then the 'best practice' area of 'knowledge management' is an appropriate choice. A demo-cratic dialogue conference may be a good way to collect items of experience relevant to a given field on a broad basis without preselection. Benchlearning is appropriate in cases where the aim is to verify whether the company is 'on course' with regard to current developments, or to encourrage the ability of employees to learn and grow.

Benchlearning has a legacy from benchmarking in that it looks to good examples. But unlike traditional benchmarking, benchlearning is not primarily based on comparisons of calibrated key indicators but reaches out farther by seeking a dialogue with the good example to learn from its 'tacit knowledge', to objectivise its own operations and to revise its own mental models of the logic of those operations. To return to the simile 


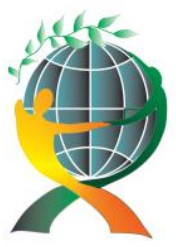

\author{
(online) $=$ ISSN $2285-3642$ \\ ISSN-L = $2285-3642$ \\ Journal of Economic Development, Environment and People \\ Volume 1, Issue 3, 2012 \\ URL: http://jedep.spiruharet.ro \\ e-mail: office jedep@spiruharet.ro
}

of the vicar viewing the churches in the city from a hill-top, we can say that benchmarking is like comparing the exterior dimensions the churches and the heights of their domes.

The learning and understanding aspects are what distinguish benchlearning from knowledge management, which - at least up to now - has been mainly concerned with retrieving information from database compilations or recorded case studies of best practice.

Like democratic dialogue and many networking schemes, benchlearning aims to achieve broad involvement and participation in the development process, to utilise other people's experience. In this respect benchlearning focuses clearly on one or more good examples who are known to be able to report excellent practice in some area of interest. The process of picking good examples is a key step in benchlearning, because it guarantees that the information communicated in the networks is of substantial economic value. We are fully aware that establishing networks is not an easy or quick process for any of the parties concerned. It takes resources both to establish and to maintain a network. Networks can promote development but, as research has proved, they can also promote secrecy. The question of whether a network makes a positive contribution to economic development or democracy seems therefore to be primarily a matter of the quality of the network and the content of what is communicated. Benchlearning offers a means of guaranteeing as far as possible that the content of the communication is valuable. The good example with whom one conducts the dialogue need not be world class, but must be good enough in comparison to the receiver that objectification generates a positive tension and an ambitious plan of action.

\title{
6. Benchlearning as a Attitude
}

What, then, do the exploding volume of data and information, the ever-faster turnover of knowledge and the ever-more-pressing shortage of time signify in terms of our attitude to using 'stored knowledge'?

One possible conclusion is that searching 'stored know-ledge' for a clue to solving our own problem is likely to become a better option than trying to solve the problem on our own. To this the objection may be raised that ever-increasing pressure of time makes it harder to 'go the long way round' via stored knowledge: finding one's own solution may be a more expensive way to solve the problem, but it is quicker. If time is of the essence, it may be better to get the answer almost right, rather than getting an ideal solution that takes too long to find. 


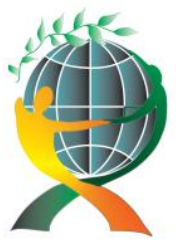

\section{Conclusions}

The learning and understanding aspects are what distinguish benchlearning from knowledge management, which - at least up to now - has been mainly concerned with retrieving information from database compilations or recorded case studies of best practice. Also, experience plays a key part in benchlearning.

\section{References}

[1] Glušica,Z.(2005). Implementacija sistema ekološkog menadžmenta ISO 14001:2004 , Novi Sad, Mobes

[2] Karlof B.,Kurt L. and Froment, M.E. (2001). Benchlearning - Good Examples as a Lever for development, Chichester, John Wiley\&Sons, LTD,England

[3] Karlof,B.(1998).Going for Excellence-Achieving Results Through Efficiency,London, The Institute of Chartered Accountants in England and Wales

[4] Malobabić,M.(2007).Razvoj modela integrisanog menadžmenta kvalitetom,životnom sredinom i bezbednošću informacija u JP informatičke delatnosti grada Novog Sada(doktorska teza),Novi Sad

[5] Malobabić,V.(2007).Benchlearning Metod u JP i JKP Vojvodine,Novi Sad, Prosveta 